\title{
Spatial fragmentation and bottom-up appropriations: the case of Safavid Isfahan
}

\author{
SOMAIYEH FALAHAT and M. REZA SHIRAZI \\ Institute of Architecture, Technische Universität Berlin, Berlin, Germany
}

\begin{abstract}
It is widely claimed that there was a clear spatial continuity in the evolution of the traditional Middle Eastern city, with every new development the result of an intelligent, albeit unplanned, evolution of pre-existing doctrines of construction. However, as far as the new Safavid urban development of seventeenth-century Isfahan (in Iran) is concerned, it is possible to distinguish a spatial fragmentation, in terms of urban pattern and urban structure, between the old texture and new extensions.
\end{abstract}

This article first presents an image of the generation and evolution of the city up to the pre-Safavid period and investigates its urban morphology. It then focuses on the new Safavid urban development that was planned, supported and executed by Shah Abbas I, to show how a top-down planning approach has generated spatial fragmentation, resulting in evident structural and geometric differences between the old and new town. It will be argued that despite this heterogeneous imposition, the spatial fragmentation at the macro level has been appropriated by the spatial mentality of the inhabitants at the micro level, and integrated into their existing life-world.

\section{Introduction}

The traditional city, in the Middle Eastern context, normally refers to the pre-modern cities of the region, which have a particular formal as well as socio-cultural structure. An integral characteristic of these cities is what is called the 'irregular, non-geometric' urban configuration clearly observable in their morphology, in contrast to what is normally presumed to be 'regular and geometric'. ${ }^{1}$ In general (although with a

${ }^{1}$ X.D. Planhol, The World of Islam (New York, 1959); P.W. English, City and Village in Iran: Settlement and Economy in the Kirman Basin (Madison, 1966); T.L. Balbás, 'La Edad Medina', in A.G. Bellido (ed.), Resumen histórico del urbanismo en Espaňa (Madrid, 1968); L.C. Brown, 'Introduction', in L.C. Brown (ed.), From Madina to Metropolis (Princeton, 1973); P. Wheatley, 'Levels of space awareness in the traditional Islamic city', Ekistics, 253 (1976), 354-66; L. 
few exceptions), Middle Eastern cities have evolved through a bottomup process, without any pre-imposed comprehensive plan, on the basis of the socio-cultural structure of the city, wherein ethnic classification and religious affiliation have played a vital role in the establishment and evolution of neighbourhoods.

The city of Isfahan is a specific case where the later planned developments contributed by the Safavid king in the seventeenth century are in contrast with the earlier non-planned urban texture at the macro level, but it illustrates how such a strange imposition can be socially appropriated by its inhabitants to make it liveable.

This article first studies the genesis and evolution of the city of Isfahan up to the Safavid era, and shows how the city assumed its morphology through a top-down process. Subsequently, the new urban Safavid developments will be introduced, and it will be argued that these have imposed a different urban geometry onto the structure of the city. Finally, it will be argued that this imposed geometry has been appropriated by the citizens at a micro scale in their ways of inhabiting the space.

\section{Pre-Safavid Isfahan, morphology and evolution}

\section{Genesis and evolution of the city}

According to historians and geographers, at the time of the Arab invasion in the seventh century, in the present-day location of Isfahan, there existed two main settlements of Yahudiyya and Jayy, lying about $4 \mathrm{~km}$ apart (Figure 1). Jayy, today identified with the village of Shahristan, was located on the north bank of Zayande-Rud, on the east side of the modern city. Originating with the imperial order of Firuz, who reigned from AD 459 to $483,{ }^{3}$ it was a circular Sassanid city with four gates, whose locations were determined by certain seasonal positions of the sun and astronomical

Benevolo, The History of the City (London, 1980); A.W. Najmi, Herat, the Islamic city (London, 1988); C. Norberg-Schultz, The Concept of Dwelling (Milan, 1985); S. Kostof, The City Shaped: Urban Patterns and Meanings through History (Boston, MA, 1991); D. Eigner, 'Zur Entstehung des "islamischen" Stadtbildes', in A. Machatschek, M. Kubelík and M. Schwarz (eds.), Von der Bauforschung zur Denkmalpflege (Vienna, 1993), 51-64; A. Beattie, 'Damascus', in T. Ring and R.M. Salkin (eds.), International Dictionary of Historic Places, 4 vols. (Chicago, 1994-96); H. Lindemann, Stadt im Quadrat, Geschichte und Gegenwart einer einprägsamen Stadtgestalt (Braunschweig, 1999); L.R. Ford, The Spaces between Buildings (Baltimore, 2000); T. Bianquis, 'Urbanism', in J.W. Meri (ed.), Medieval Islamic Civilization:An Encyclopedia, 2 vols. (New York, 2006), 849-51.

2 W. Blunt, Isfahan: Pearl of Persia (New York, 1966); L. Honarfar, A Treasure of the Historical Monuments of Isfahan (Tehran, 1971).

${ }^{3}$ Blunt, Isfahan. 


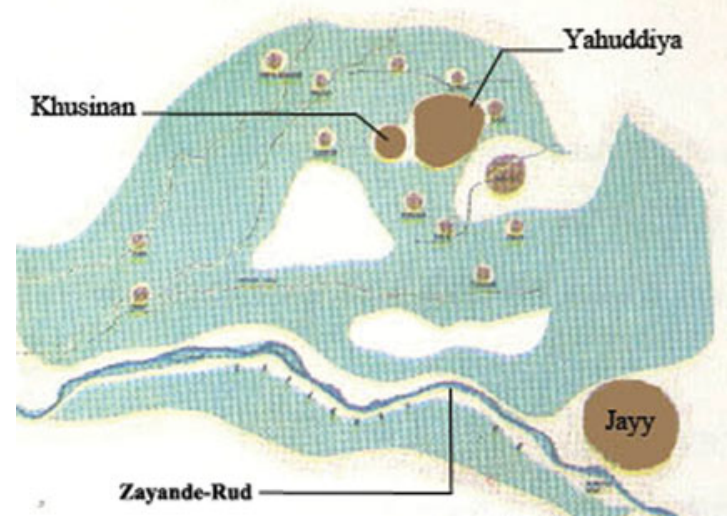

Figure 1: (Colour online) The location of Jayy and Yahudiyya in the region of Isfahan, modified from Isfahan, The City of Light, British Museum, 6 May - 11 July 1976.

calculations. ${ }^{4}$ Jayy was divided into four parts by its two main axes, following the religious doctrine of the Zoroastrians. ${ }^{5}$

Yahudiyya, literally the Jewish quarter, has been identified with the existing large quarter of Jubara at the north-east of Masjid-i Jami (Old Jami Mosque). It belonged to a Jewish colony that settled in this region long before the foundation of Jayy, and its origin is supposed to date back to the time of Nebuchadnezzar $\mathrm{II}^{6}$ (634-562 BC). ${ }^{7}$ Following their expulsion by the king, the Jewish migrants started to search the world for a place whose 'soil' was similar to Jerusalem's, and finally alighted upon this area. ${ }^{8}$

However, the foundation of Isfahan rested upon a political decision made in the eighth century, when an Abbasid governor had to be settled in this region. In AD 767-68, the governor set up residence in the village of Khusinan, between Jayy and Yahudiyya, whereby the new centre of the area was transferred from Jayy to Khusinan. Consequently, a new urban core was established at some distance from the older one. The governor

${ }^{4}$ A.R. Mehrabadi, Athar-e Melli-ye Esfahan (The National Monuments of Isfahan) (Tehran, 1973); H. Sultanzade, Muqaddamai bar tarikh-i shahr wa shahrnishini dar Iran (Introduction to the History of Cities and Urbanism in Iran) (Tehran, 1988).

${ }^{5}$ Zoroastrianism is a religion and philosophy which served as the state religion of a significant portion of the Iranian people for many centuries. It was founded before the sixth century $\mathrm{BC}$ and was gradually marginalized by Islam from the seventh century onwards. For more information, see M. Boyce, Zoroastrians: Their Religious Beliefs and Practices (London, 1979); P. Clark, Zoroastrianism. An Introduction to an Ancient Faith (Brighton, 1998); M.N. Dhalla, History of Zoroastrianism (New York, 1938).

${ }^{6}$ Nebuchadnezzar II (634-562 BC) was the king of the Neo-Babylonian Empire, and reigned from 605 to $562 \mathrm{BC}$. According to the Bible, he conquered Judah and Jerusalem, and sent the Jews into exile. He is credited with the construction of the Hanging Gardens of Babylon.

7 L. Golombek, 'Urban patterns in pre-Safavid Isfahan', Iranian Studies, 7 (1974), 18-44.

8 Mehrabadi, Athar-e Melli-ye Esfahan; Golombek, 'Urban patterns in pre-Safavid Isfahan'. 
built a new mosque overlooking the banks of a canal, the Nahr Fursan, on the opposite side of his palace-complex, on the site of the present-day Shaya mosque. ${ }^{9}$ Correspondingly, he built a large maidan-bazaar on the outskirts of Khusinan, which made Yahudiyya a common point between the two villages. These elements - bazaar, mosque and palace - were the main urban components of the Islamic-Arabic cities during the ninth and tenth centuries. ${ }^{10}$

After a while, the governor was removed from Isfahan and the development of this new urban core was continued by the Arabs who settled in the nearby villages. In AD 772, the present-day Masjid-i Jami was constructed and became the most important mosque in the entire area. ${ }^{11}$ The two existing settlements grew gradually and, by the eighth century, were beginning to converge, after which the combined settlement took the name of Yahudiyya. ${ }^{12}$ Subsequently, while Jayy remained as a small village, Yahudiyya transformed into the most important settlement of the region, with a large Friday mosque in the centre of a bustling bazaar, visited daily by large crowds of people.

The tenth century is considered as the period of greatest social and cultural fermentation and urban civilization in Iran. ${ }^{13}$ Due to its political autonomy and integrity, Iran experienced a period when the arts, sciences, literature and urban development particularly flourished, a phenomenon which can also be witnessed in the urban life of Isfahan. In fact, until the tenth century Isfahan was mainly a village-like settlement, but under Al-Buyids rulers (AD 932-1055), the city made its next important strides in urban development and, in fact, gained its initial city-structure with defined city walls, gates, neighbourhoods, main arterial roads and a main central square. A dominant change influencing the circumstances of this period was the flowering of trade. Its apparent effect was to engender recognition of Yahudiyya/Isfahan, a village on the caravan route, as a city in its own right. At this time, part of the town was encircled with a defensive wall with 12 gates and a strong citadel was built in the southwestern quarter. Furthermore, a couple of buildings and public spaces were erected, such as the Jurjir Mosque, the madrasa of Ibn Sina and the Maydan-i Mir at the centre. ${ }^{14}$ The interior area was divided into four major mahallas (residential quarters), named Jubara, Karan, Dardasht and Kushk, the first of these corresponding to the ancient settlement of Yahudiyya (Figure 2). Karan occupied the south-eastern quadrant. Dardasht as a mahalla incorporated the villages of Yavan and Chumulan

${ }_{9}^{9}$ Golombek, 'Urban patterns in pre-Safavid Isfahan'.

${ }^{10}$ H. Gaube, Iranian Cities (New York, 1979).

11 Gaube, Iranian Cities; S.P. Blake, Half the World: The Social Architecture of Safavid Isfahan, 1590-1722 (Costa Mesa, CA, 1999).

12 Gaube, Iranian Cities.

13 P. Beaumont, G.H. Blake and J.M. Wagstaff, The Middle East: A Geographical Study (London, 1976).

${ }^{14}$ Golombek, 'Urban patterns in pre-Safavid Isfahan'. 


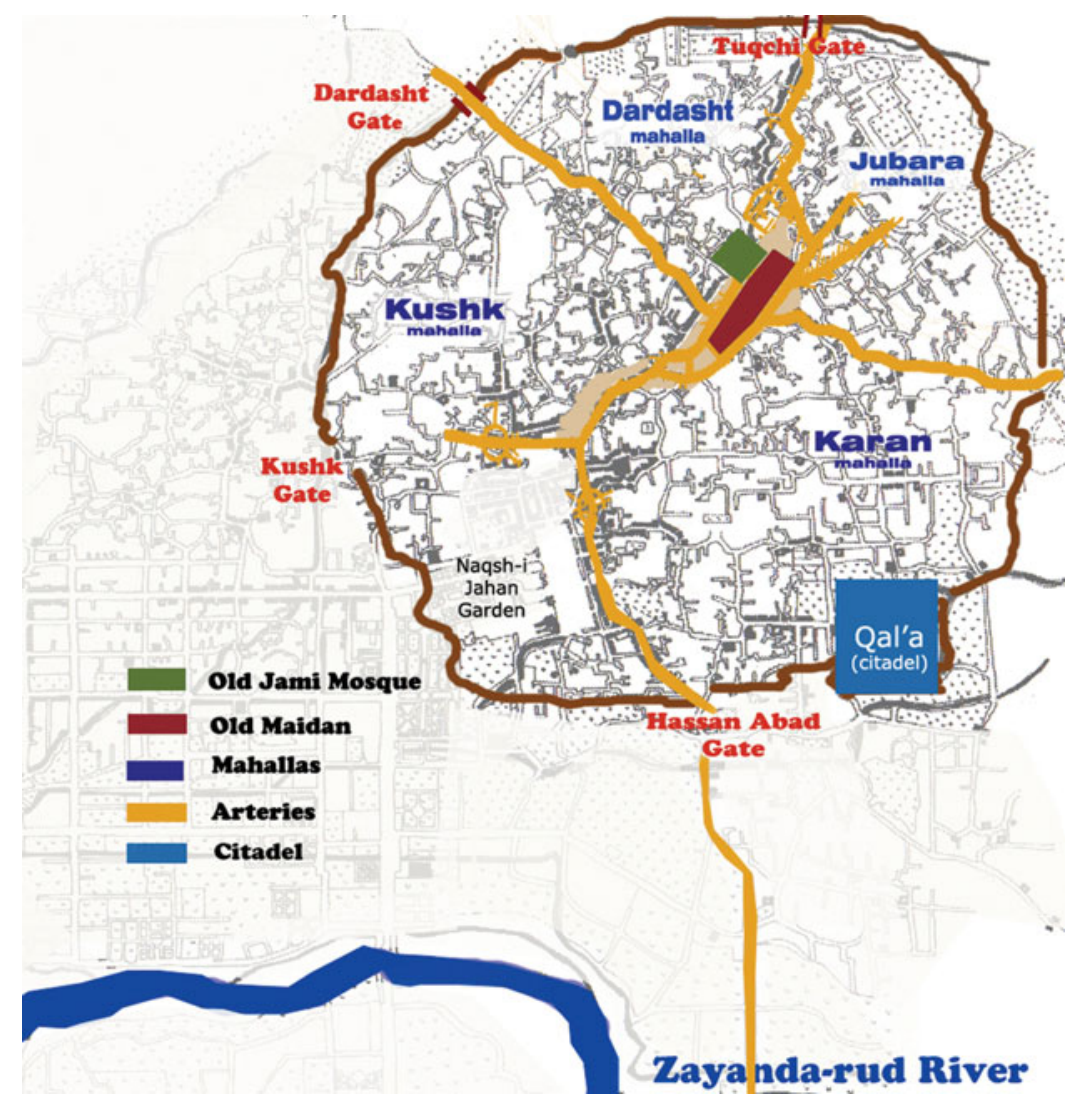

Figure 2: (Colour online) Structure of Isfahan during the twelfth century. This figure shows Seljuqid Isfahan with its four major neighborhoods, its centre (old maidan and Friday mosque), the citadel, main city arteries and gates. The background map is modified from $\mathrm{K}$. Herdeg, Formal Structure in Islamic Architecture of Iran and Turkistan (New York, 1990), and the over map is based on the studies of H. Gaube, Iranian Cities (New York, 1979), 80, and L. Golombek, 'Urban patterns in pre-Safavid Isfahan', Iranian Studies, 7 (1974), 18-44.

(also called Sunbulan). The remaining south-west quadrant of the walled city, which later became the Safavid quarter of Dawlat, at that time bore the name Kushk. It is also listed by Qazvini, along with Jubara, Karan and Dardasht, as one of four original villages that were joined together to form Isfahan. These four quarters constitute the quadrants of a circle or oval, and the centre where the quarters meet falls at a point just south of the Old Jami Mosque. ${ }^{15}$

15 Isfahan, the City of Light, British Museum, 6 May - 11 July 1976, an exhibition organized by the Ministry of Culture and Arts of Iran (Tehran: Ministry of Culture and Arts of Iran, 1976). 
Due to the importance of trade in this era, the trade route was integrated into the city, which resulted in the emergence of the four main axes of old Isfahan, which were lined with shops and workshops, forming the linear arterial bazaars of the city. ${ }^{16}$ A series of passages (Koochehs) within each of the quarters were connected to the gates. The old maidan (square), located in the intersection of the axial bazaars was the most important commercial, religious and administrative centre at the heart of the city. ${ }^{17}$ According to Nasir Khusrou ${ }^{18}$ - who presents the first comprehensive image of Isfahan at this time (AD 1052) - the city had 'a strong high wall with gates and fortifications, and all the walls are battlemented. Inside are channels of running water, tall handsome buildings, and in the centre of the city stands the great and magnificent Friday Mosque. ${ }^{19}$ He saw the city as very uniformly prosperous and well-managed, and this convinced him to name it the most prosperous town in the Persian-speaking realm: 'The city looks uniformly prosperous. I noticed a large number of bazaars. Each bazaar has its wall and its gates, as has every quarter and street. There are clean and well-kept caravanserais ... I have never seen, anywhere where Persian is spoken, a finer, larger or more prosperous town than Isfahan. ${ }^{20}$ This flourishing process continued later in the Seljuk era (twelfth century) up until Mongol invaders captured the city in the thirteenth century and ruled it for about two centuries. The city remained within the borders of this original city wall for a long period (up to the sixteenth century) and developed within itself according to the city structure imposed by the Al-Buyids.

\section{Urban morphology and bottom-up evolution}

The long-term, gradual nature of the spatial development process up to the sixteenth century had the result that the pre-Safavid city has a homogeneous urban structure where one spatial configuration is observable over the entire extent of the settlement. As discussed earlier, at its beginning, the core of the city consisted of a small village without any particular urban element, located between two important nuclei of the region. This nucleus started to grow incrementally after a number of urban elements - bazaar, mosque and palace - were erected in its environs. Due to this construction, it came to function as the focal point and core of the neighbouring settlements and continued to grow, shaping a circular city with a maidan at its centre. As has been mentioned, in the course of this process, the governor constructed the public urban buildings, while

${ }^{16}$ Golombek, 'Urban patterns in pre-Safavid Isfahan'; Gaube, Iranian Cities.

17 Gaube, Iranian Cities.

18 Nasir Khusrou (AD 1004-88) was a Persian poet, philosopher, scholar and traveller. Safarnama, an account of his travels, is his most famous work.

${ }^{19}$ Blunt, Isfahan, 23.

${ }^{20}$ Ibid. 
the remainder - which was the majority of the settlement - was built up incrementally by the inhabitants.

When in a later era of prosperity the city saw a period of considerable growth, this was mainly a bottom-up process. Although the governors also took part in the city's development, their role was limited to the erection of some single, though major, urban elements - such as mosques or city walls. At a macro scale, the main components of the city's structure in this era were the formation of the neighbourhoods, the emergence of the linear bazaar and the construction of the city wall. The building of the wall was ordered and guided by Hassan Rokn-Al-Dowleh, one of the rulers of the Al-Buyid dynasty. In an astrologically proper time, he decided to make a wall to be built around the existing built area of the settlement. ${ }^{21}$ The city inside the walls was divided into different parts and its four neighbourhoods were determined by integrating the constituent settlements, including Yahudiyya as the original settlement of Isfahan, and the other nearby villages. The people who were living in these areas became absorbed into the city by virtue of remaining in their previous environment and the agglomeration was unified within the city walls. Then, with the rising centrality of trade, the trade route passing alongside the city was integrated into the city's geometry, creating the bazaar arteries. These arteries were laid out on an ancient regional trade route and came to buzz with activity when the people started to adopt them for their commerce. From this, it can be concluded that prosperity and the desire for the city development were not embodied through the imposition of large-scale pre-conceived plans; rather, they took concrete form through the consolidation of existing points and potentialities. Put more specifically, this means that the ratio of the city's area developed by the authorities (consisting of a number of public buildings), compared to the area that was built up incrementally by ordinary citizens, is very small.

The same principle is also present at the micro level and the way the mahallas were organized internally indicates a further dimension of this bottom-up process. The urban administration in most of the cities within the Islamic context was not conducted by a city council, charged with overall responsibility for town management; instead, the quarters and social groups managed themselves in an autonomous way, rather than through a disciplined systematic order dictated from the top. According to this scheme, most of the services were provided by the leaders of each neighbourhood, and the city quarters were responsible for their own well-being. ${ }^{22}$ Moreover, due to religious law, any kind of priority and subsequent separation according to wealth and race was strongly forbidden $^{23}$ so that 'class distinctions were not recognized in law, and

${ }^{21}$ L. Honarfar, Ashnaii ba Shahr-e Tarikhi-e Esfahan (The Historic City of Isfahan) (Tehran, 1994), 44.

${ }^{22}$ M. Kheirabadi, Iranian Cities: Formation and Development (Austin, 1991).

23 S.M. Habibi, Az Shar ta Shahr (de la Cité à la Ville) (Tehran, 2006). 
were not considered right in practice'. ${ }^{24}$ However, the emergence of different religions and denominations resulted in strong connections being forged between co-religionists, which also displaced the importance of any economic ranking. Consequently, people with different ethnic origins and religions, such as Jews and Christians, began to live separately and to build exclusive mahallas. The social solidarity of these mahallas was based on 'religious identity' as well as 'ethnic' or 'sectarian religious affiliation ${ }^{\prime 25}$ providing some 'strong micro-communities' which were selfreliant insofar as each one formed a 'virtual autonomous social unit'. ${ }^{26}$ Therefore, a neighbourhood was a cluster of households characterized by a particular quality of social affiliation based on multiple personal ties, common interests and shared moral unity. ${ }^{27}$ Neighbourhood communities provided basic shared facilities, and controlled and managed '[ $t]$ he irrigation networks and the internal access system connecting the houses with the major public thoroughfares'. ${ }^{28}$

The outcome of this urban evolution in pre-Safavid Isfahan indicates a life-world that the inhabitants shared and practised together over a long period of time. In fact, the morphology resulted from the way people settled down, inhabited the environment and organized their domestic life. An integral part of this dwelling style was rooted in the socio-cultural characteristics of urban life, in which mahallas had a kind of independence in their administrative affairs and management. ${ }^{29}$ This resulted physically in the spatial configuration of a centripetal city built around the maidan with its related components, such as the Jami Mosque, together with some roadways ramifying from the maidan, leading to secondary routes, and culminating in residential units. This spatial configuration follows the logic of bottom-up city making at both the macro and micro level, with little space left for major top-down planning.

\section{Safavid developments, imposition of a new urban geometry}

\section{Safavid new developments}

Following the Mongol invasion of the thirteenth century, there was longterm stagnation in the urban development of Isfahan, lasting till the rise of the Safavid dynasty at the beginning of the sixteenth century. To begin with, the main concern was the embellishment of the old maidan. Around it, four major urban buildings - a madrasa (school), a shrine, the Ali Mosque and

\footnotetext{
${ }^{24}$ M. Keyvani, Artisans and Guild Life in the Later Safavid Period: Contributions to the SocialEconomic History of Persia (Berlin, 1982), 39.

${ }^{25}$ I.M. Lapidus, Muslim Cities in the Later Middle Ages (Cambridge, 1967).

${ }^{26}$ S. Bianca, Urban Form in the Arab World: Past and Present (London and New York, 2000), 152-3.

27 D. Eickelman, The Middle East: An Anthropological Approach (Englewood Cliffs, 1981).

${ }^{28}$ Bianca, Urban Form in the Arab World, 153.

${ }^{29}$ Habibi, Az Shar ta Shahr; Bianca, Urban Form in the Arab World; Kheirabadi, Iranian Cities.
} 
a caravanserai - were constructed; while along the road leading from the maidan to the south-west of the city were built two mosques, one madrasa and one hammam (bath). ${ }^{30}$

In the winter of 1597, Shah Abbas-I decided to transfer his capital from Qazvin to Isfahan due to its central location, excellent climate and good access to water. ${ }^{31}$ The result was that merchants from all over the world began flocking to the city, seeking trading privileges, and it became the preferred base for numerous ambassadors and representatives of foreign monastic orders. ${ }^{32}$ These events brought prosperity to Isfahan, and raised it to its highest point of development, making it a capital of intercontinental importance. However, in order to make Isfahan a 'fitting metropolis', Shah Abbas decided that drastic changes to the city's structure were needed. ${ }^{33}$

The main feature of Shah Abbas' new scheme was moving the core of the city to the south, which at that time featured a garden called Naqshi Jahan and thus provided a suitable location for development, and the construction of magnificent new buildings around it (Figure 3). ${ }^{34}$

The new urban development took place in two phases. The first phase, from 1598 to 1606, saw the construction of the new maidan, the Ali-Qapu (royal castle), Chahar-Bagh Avenue, together with the Allah-Verdi-Khan Bridge across the river, and the Lotfollah-khan Mosque. The second or major phase began in 1611-12, when some of the buildings around the maidan, such as the royal mosque (Abbasid Jami Mosque) and the entrance to the Qaysaria (royal bazaar) were constructed (Figure 4). ${ }^{35}$ Though Safavid Isfahan was founded by Shah Abbas in 1602, it only acquired its ultimate form in about 1722, following extensive constructions built by various prominent citizens over the course of the rest of the seventeenth century. ${ }^{36}$

Overall, however, the Naqsh-i Jahan Square together with the ChaharBagh can be said to be the two key features of Shah Abbas' master plan for Isfahan. Naqsh-i Jahan Square, which included two mosques, a government complex (Ali-Qapu) and a Bazaar (Qaysaria), was supposed to be the 'center of the new city'. ${ }^{37}$ It was an enormous, multi-functional open space, approximately $507 \mathrm{~m}$ long and $158 \mathrm{~m}$ wide, laid to the east of the northern end of the Chahar-Bagh and at a slight angle to it, surrounded by a uniform portico-screen of two storeys with a commercial function. It provided a locus for a range of functions which varied from polo games and the focal point for all festival performances to the accommodation

30 Gaube, Iranian Cities.

31 Blunt, Isfahan.

32 R. Savory, Iran under the Safavids (Cambridge, 1980).

33 L. Lockhart 'Shah Abbas's Isfahan', in Arnold J. Toynbee (ed.), Cities of Destiny (London, 1976), 219.

34 Ibid.

35 Ibid.

36 Blake, Half the World.

37 K. Herdeg, Formal Structure in Islamic Architecture of Iran and Turkistan (New York, 1990). 


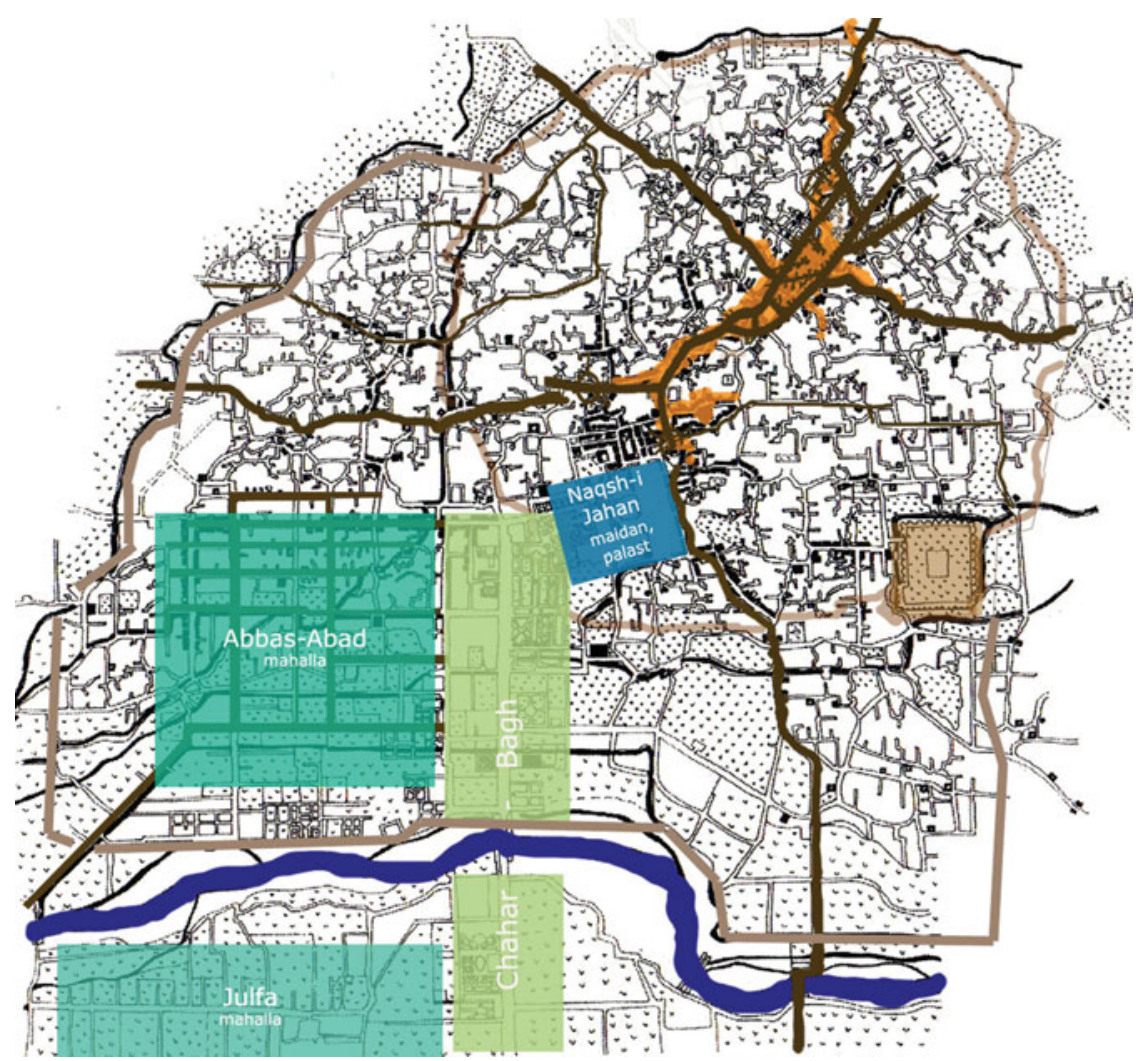

Figure 3: (Colour online) New elements added by Safavids, modified from K. Herdeg, Formal Structure in Islamic Architecture of Iran and Turkistan (New York, 1990).

of caravans. ${ }^{38}$ In fact, this new maidan had the same pattern as the old maidan, but was more spacious and luxurious (Figure 5).

Chahar-Bagh was designed as a garden-avenue, a paved pathway for pedestrians lined with rows of trees and water channels, ${ }^{39}$ which began from the eastern side of the castle, crossed over the river and culminated in the garden of Hezar-Jarib. ${ }^{40}$ This street was later flanked by the gardenpalaces and garden-mansions of princes and grandees. In the alleys running from the avenue, there were water runnels and rows of plane trees. ${ }^{41}$ Some of the pavilions which flanked the avenue were 'places of public resort and were used as coffee-houses where ... the good burghers

38 Ibid.

39 G.N. Curzon, Persia and the Persian Question, vol. II (London and New York, 1892).

40 W. Barthold, An Historical Geography of Iran (Princeton, 1984).

41 J. Chardin, Travels in Persia 1673-1677 (New York, 1971). 


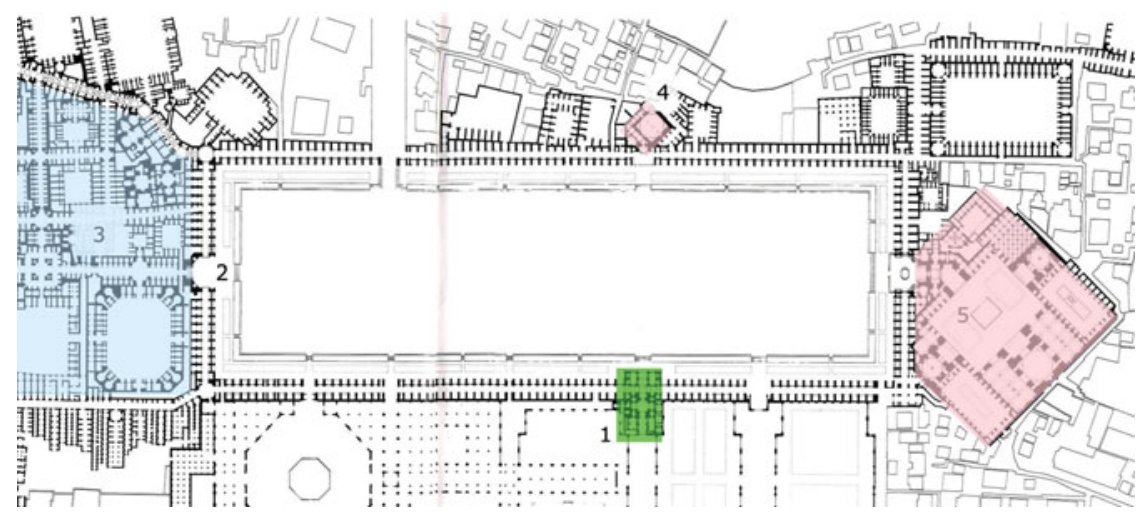

Figure 4: (Colour online) Naqsh-i Jahan Maidan, modified from K. Herdeg, Formal Structure in Islamic Architecture of Iran and Turkistan (New York, 1990): (1) Ali Qapu, (2) Gate of Qaysaria, (3) Qaysaria, (4) Sheikh Lotfollah Mosque, (5) Abbasid Jami Mosque.

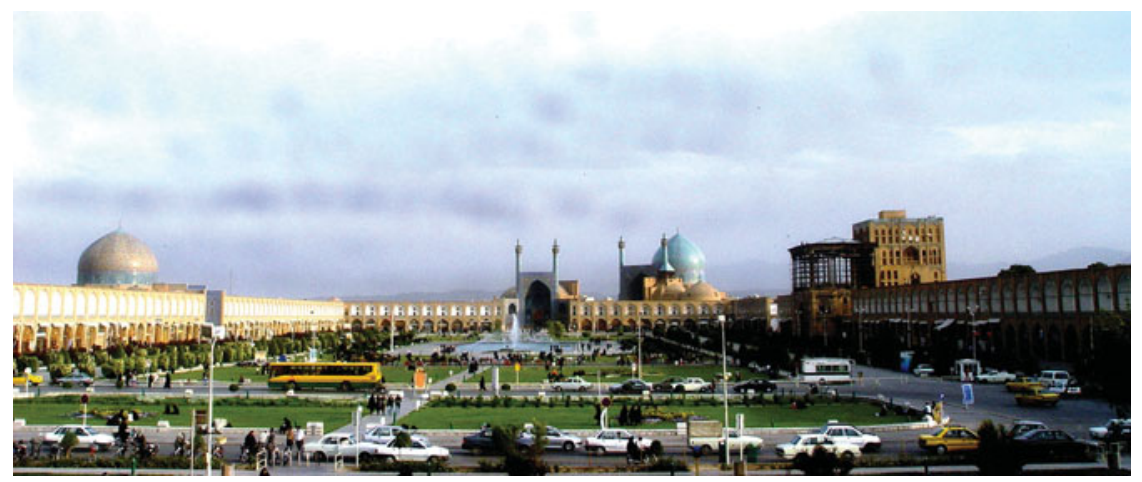

Figure 5: (Colour online) Naqsh-i Jahan Maidan, present day (source: authors).

of Isfahan assembled to sip that beverage and to inhale their kalians [hookahs]' ${ }^{42}$ Before the construction of the surrounding mansions and quarters, namely at the time when the Shah ordered the construction of this street, Chahar-Bagh was located outside the city. But after a while, the building of the new mahallas altered its location so that it was now at the centre. ${ }^{43}$ It played the role of a connecting route in the structure of the city, linking the north to the south and the west to the east. ${ }^{44}$

42 Curzon, Persia and the Persian Question, 38, 39.

43 A. Esmaeeli, 'Chahar-Bagh dar Safarnameha' (Chahar-Bagh in travel literatures), Golestan Honar, 5 (2006), 39-47.

44 J. Brignoli, 'Bineshe Shah Abbas: Shahrsazi Saltanati Isfahan (La vision du prince: Urbanisme royal d'Isfahan)', trans. D. Tabaee, Golestan Honar, 5 (2006), 60-71. 
Besides these two major construction sites, a number of new residential quarters were erected to accommodate migrants: Abbas-Abad Mahalla in the west of Chahar-Bagh for Tabrizis ${ }^{45}$ and New Julfa Mahalla at the south of the river for the thousands of skilled Armenian artisans who were transferred from the city of Julfa in north-west Iran. ${ }^{46}$

\section{Spatial fragmentation and top-down imposition}

Safavid developments, compared to the pre-Safavid era, present a different logic and spatial vocabulary. The Safavid king's efforts to develop the old city centre failed, because of the difficulties he faced in gaining possession of land and satisfying the existing landlords. A strategic change was to shift new developments towards the southern parts of the city, free from any serious physical restrictions.

The new developments, incorporated into the four areas of the new Naqsh-i Jahan Square, Chahar-Bagh Avenue and the Abbas-Abad and Julfa residential quarters, obviously differ from the old city in terms of geometry and urban pattern and thus create a spatial fragmentation over the entire city. On the one hand, the organic geometry of the old city is replaced by the regular grid-like geometry of the new developments. This regularity is not restricted to the public-administrative areas of Naqsh-i Jahan and Chahar-Bagh; it includes the residential quarters of AbbasAbad and Julfa as well. On the other hand, the new maidan of Naqsh-i Jahan was supposed to replace the centrality of the old maidan; however, on the ground the mono-focal structure of the old city transformed to a bi-focal structure, whereby the new maidan was mainly in the service of governmental activities and regional functions, the old maidan in the service of lower-class and local purposes. ${ }^{47}$

In this era, in general, there existed three levels of authority operating at the macro, intermediate and micro scale: these were the king, the elite and the common people. The king as the head of the country and the capital was the most powerful person in the realm, with an authority that enabled him to realize his intentions and preferences. He was able to mobilize the people at all social levels, order them and organize them. In the case of Isfahan, his authority was so powerful that Isfahan has been considered by a number of authors as the city of Shah Abbas. For example, Blake believes that Safavid Isfahan was built by Abbas-I; ${ }^{48}$ Blunt declares that 'Isfahan is Shah Abbas's memorial'; ${ }^{49}$ Savory states that the king was the creator of the city and writes 'Rarely in the course of history has an entire city been planned or re-planned at one time by a master mind (King) ${ }^{\prime}, i^{\prime}$

\footnotetext{
45 The name for the people of Tabriz.

46 Savory, Iran under the Safavids.

47 Blake, Half the World; Blunt, Isfahan.

48 Blake, Half the World.

49 Blunt, Isfahan, 13.

50 Savory, Iran under the Safavids, 154.
} 
and Lockhart asserts that 'He [the king] re-planned and largely rebuilt the city, personally supervising a great part of the work. ${ }^{51}$

Nobles and other prominent citizens used to erect public buildings in the city to gain social trust and popularity. They participated in the development of the city at an intermediate level, constructing public buildings in the neighbourhood centres, such as caravanserais, baths and mosques, and acted as the patrons and protectors of their mahalla. As Blake declares: 'The dominance of high-ranking tribal or slave Amirs in the construction of the Mahalla center reflected their standing in neighborhood politics. $^{52}$

As far as the Safavid developments are concerned, these were based on a top-down planning approach founded on the absolute authority of the king, with the support of the nobles and prominent citizens. While the king set out the entire development agenda and built the new city centre, the nobles constructed the centre of the mahallas or erected new buildings alongside the Bazaar. To take advantage of their capacity, the Safavid king asked the nobles to participate in the realization and success of his ideas and plans. Shah Abbas started the construction of Chahar-Bagh Avenue in 1596. In the same year, he divided the lands along the avenue between the nobles, who included Khans, Amirs, Viziers and religious officials, and ordered them to build 'sumptuous Chahar-Baghs'. In response, 25 large garden retreats were built by high-ranking Amirs, flanking both sides of Chahar-Bagh Avenue, the long thoroughfare that stretched from the Daulat Gate to the Abbas-Abad Chahar-Bagh. ${ }^{53}$

A comparison between urban developments during the city's two major eras of flourishing, the Al-Buyid and the Safavid, shows two different approaches and understandings with regard to urban intervention. First, there is no evidence which implies the provision of a master or development plan by the governors, or the king, in the Al-Buyid era. Urban development was thus based not on the imposition of an 'image' originating in the mind of the governor onto the existing urban texture, but on a series of constructions manifested in single buildings (mosques, baths, madrassas, etc.) or urban scale structures such as the city wall. Secondly, new constructions had an infill character, in the sense that they were planned to fill the existing urban pattern; there was no large-scale extension to the city. In other words, urban development took place either within the city or in its immediate periphery, unlike the case of Safavid Isfahan which embraced immense urban extensions to the existing city area. Thirdly, and the most importantly of all, the geometry of new urban developments and constructions in the Al-Buyid era retained the character and logic of the existing urban pattern; there is no historical evidence showing any kind of 'distinction' or 'difference' in terms of urban pattern of

51 Lockhart, 'Shah Abbas's Isfahan', 23.

52 Blake, Half the World, 85.

53 Ibid. 
pre-Al-Buyid and Al-Buyid eras. By contrast, the urban geometry of the Safavid developments depicts a clear 'difference' with the existing urban pattern, well reflected in the writings of visitors, and distinctly observable when compared to the old city. Thus, although Al-Buyid urban developments played a vital role in the evolution and construction of Isfahan and gave the city a particular identity and character, they were neither based on a top-down, solid imposition of any kind of pre-conceived 'image', nor did they follow an unfamiliar urban pattern and layout.

\section{Discussion: social appropriation and bottom-up adaptation}

Generally speaking, the urban texture of the pre-modern city in the Middle East, including Isfahan, was mainly developed by the common people, as they built their private properties and houses. These houses, the size of which differs according to the wealth of their owners, have been amassed in gradual accretions over time. The arrangement of these houses has not followed any clear-cut geometrical order in terms of the parcel of land allocated to each house, the access provided for the neighbourhoods or the width of streets and passages. Thus, the mahalla was mainly built by the common people, while nobles and prominent citizens at the intermediate level would provide public services for the entire mahalla, including the bath and mosque. This bottom-up construction, however, could not be said to be absolutely devoid of any plan. In fact, outside of some city-wide rules concerning tax and water, other regulations in the mahallas were generated internally and accepted by all. ${ }^{54}$ These internal rules and norms provided a guideline for any construction and development, and included a strong desire for privacy, respecting neighbours' privacy, gathering together in the same place people of the same profession or ethnicity, problem-solving through compromises within the mahalla through the help of the Kadkhoda, the Islamic way of dividing up plots of land, the independent authority of each mahalla, householders taking responsibility for their own alley and the housholder's right to have access to the traffic network of mahalla. Thus, residents constructed their buildings and occupied public areas and routes according to loose domestic ordinances, without any very dominant control being exercised in the area by a political or municipal organization in the form of building codes.

This way of building the city indicates a style of urban development that is rooted in the indigenous way of life and existential mentality of the citizens. They built their dwellings in a manner which met their expectations for habitation and settling a place. This mentality, although it may generate an environment which seems irregular and non-geometric

54 Besim Hakim in his book Arabic-Islamic Cities: Building and Planning Principles (Costa Mesa, CA, 1986) elaborates some of these socio-cultural regulations. 
on the surface, has its own order and logic, partly derived from existential dispositions which are archaic and pre-historic, partly based on physical contingencies and climatic requisites, partly rooted in religious norms and regulations and partly derived from social considerations. All this formed a kind of weak framework implemented through a smooth mechanism of application and control, which was far from the solid structure of a top-down imposed approach. In other words, city-making and citydevelopment was happening in a space-in-between, the regulations of which derived from the life-world of the inhabitants. In this sense, it could not be considered to be a top-down approach, since it was not imposed by force or power.

However, on the surface, the case of Isfahan in the Safavid era appears to be an exception. In this case, as explained, the king imposed a new structural order onto the structure of the city, so at the macro level a clear spatial fragmentation can be observed, providing a geometric contrast between the so-called irregularity of the old city and the regularity of the new developments. This schism indicates a different style of urban evolution, a rapid top-down development in contrast to the gradual, longterm bottom-up evolution. There is enough evidence to argue that this imposition of a new order onto the old city has the characteristic of a 'morphological break' with the past, supported by a set of functional and political forces such as 'the urgency of a short term development', 'political power', and 'practicability'.$^{55}$ However, a close investigation of the urban texture at the micro level reveals the hidden aspects of the urban pattern. Although there exists a new regular order governing the urban geometry in the new developments, the interior spaces of the urban blocks have been built up through the same spatial mentality as before; culs-de-sac are still observable and the surviving buildings and houses reveal that the building typologies are identical to those of the old city, with a typical introverted spatial configuration. This indicates that the imposed, top-down, macro order of the city has been appropriated by the people to make it liveable. In other words, they have found a way of inhabiting the strange order and made it appropriate for their style of life. This is clearly observable in Figure 6: while at the macro level, the imposed geometry of the new developments demonstrates a sense of regularity (Figure 6a) in contrast to the organic geometry of the old city (Figure 6b), the spaces in between the lines of the regular geometry have been filled according to the logic and geometry of the old city (Figure 6c). Thus, the imposed geometry has been appropriated by the inhabitants according to their experienced and lived urban pattern, so they have inhabited the spaces in between the lines of the new, imposed regular geometry according to the pattern of the old city. This was possible due to the independence and autonomy

55 The authors have elaborated the nature of this break applying the concept of 'genius loci' in S. Falahat and M. Reza Shirazi, 'New urban developments in Safavid Isfahan, continuity or disjuncture?', Planning Perspectives, 27 (2012), 611-24. 

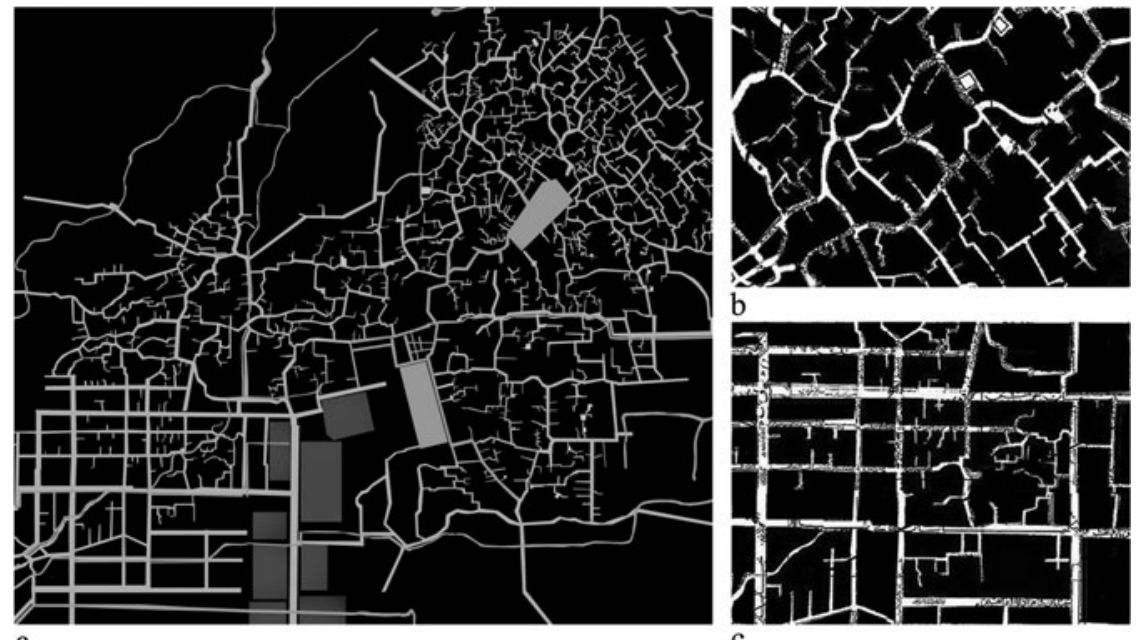

c

Figure 6a: Organic geometry of the Old Isfahan in contrast to the imposed regular geometry of the Safavid developments; $6 \mathbf{b}$ : organic geometry of the Old Isfahan; $6 c$ : bottom-up appropriation of the imposed geometry at the micro scale; based on Seyed-Reza-Khan Map.

the neighbourhoods practised in regulating, managing and planning for space, which meant that they remained free within the imposed top-down geometry.

\section{Conclusion}

The urban morphology of Middle Eastern cities has been the result of a continuous interaction between tangible and intangible factors, as the result of a long-term, bottom-up process of evolution. In the case of Isfahan, however, the new urban developments of the Safavid era in the seventeenth century created a spatial schism in the old morphology of the city, a clear spatial fragmentation imposed through a top-down mechanism. This dual urban geometry, observable at the macro level, did not, however, generate a new spatial and typological configuration at the micro level, so that the same spatial structure has been reproduced at the neighbourhood scale.

This phenomenon can be clearly perceived in the urban texture, where the regular geometry of the residential areas of the new developments in the southern part of the city have been constructed based on an appropriation of the typo-morphology that characterized the old residential quarters of the pre-Safavid city. This means that the regular imposed geometry of top-down planning has been appropriated by the 
inhabitants in a bottom-up process. In other words, as far as dwelling and settling are concerned, the residents of the city have inhabited the space according to their own particular spatial mentality.

The case of the new Safavid developments, in terms of character and structure, was very unique of its kind, so that there is no similar case of pre-modern urbanism in Iranian cities. This uniqueness derives from the size, approach and structural character of the new developments. In terms of size, these new developments covered vast tracts of land, with the construction of a number of mega urban complexes of different kinds, such as the Naqsh-i Jahan Square which had governmental as well as public components, Chahar-Bagh which was for entertainment, and Abbas-Abad which had a residential character. From the point of view of the guiding approach, one may argue that the new developments basically originated from a 'plan' defined by the king, by which he intended to manifest his power and authority in creating an ideal capital city. This top-down process of city-making left little space for citizens' involvement, and was in contrast to the existing city-making tradition, which was essentially mahalla-based with a bottom-up character. Furthermore, the geometry and urban pattern which were the basis for the top-down establishment of that 'plan' in practice contrasted with the existing geometry and urban pattern of the city, and thus resulted in the imposition of a new order on the city.

All these characteristics grant a sense of particularity and uniqueness to the case of the new urban developments of the Safavid era, which have not been observable in other Iranian cities up to the modern epoch. The only comparable case which has attracted the attention of scholars is in Tehran, where new urban developments were made by the Nasereddin Shah (1831-96), the king of Persia, some 250 years later. In 1868, some months after Nasereddin Shah's visit to Europe and the International Exhibition in Paris, he commissioned the French teacher General Bohler to provide a plan for the expansion of the capital city. New developments were located at the north of the old city and did not include the traditional city core. The new square of Tup-Khaneh was erected, which included modern western infrastructure such as the economic institution of the Imperial Bank of Persia, as well as newly established quarters for the homes of the aristocracy and the foreign embassies, and houses for European residents. In terms of urban pattern, the new developments followed a more geometric gridiron pattern in contrast to the organic geometry of the city core, thus manifesting a rupture and break with the past rather than a revival..$^{56}$

Although there are essential differences between the motivations and sources of inspiration for the new developments in each case, some structural similarities are observable: in both cases, the new developments

56 Ali Madanipour, Tehran: The Making of a Metropolis (Chichester, 1998). 


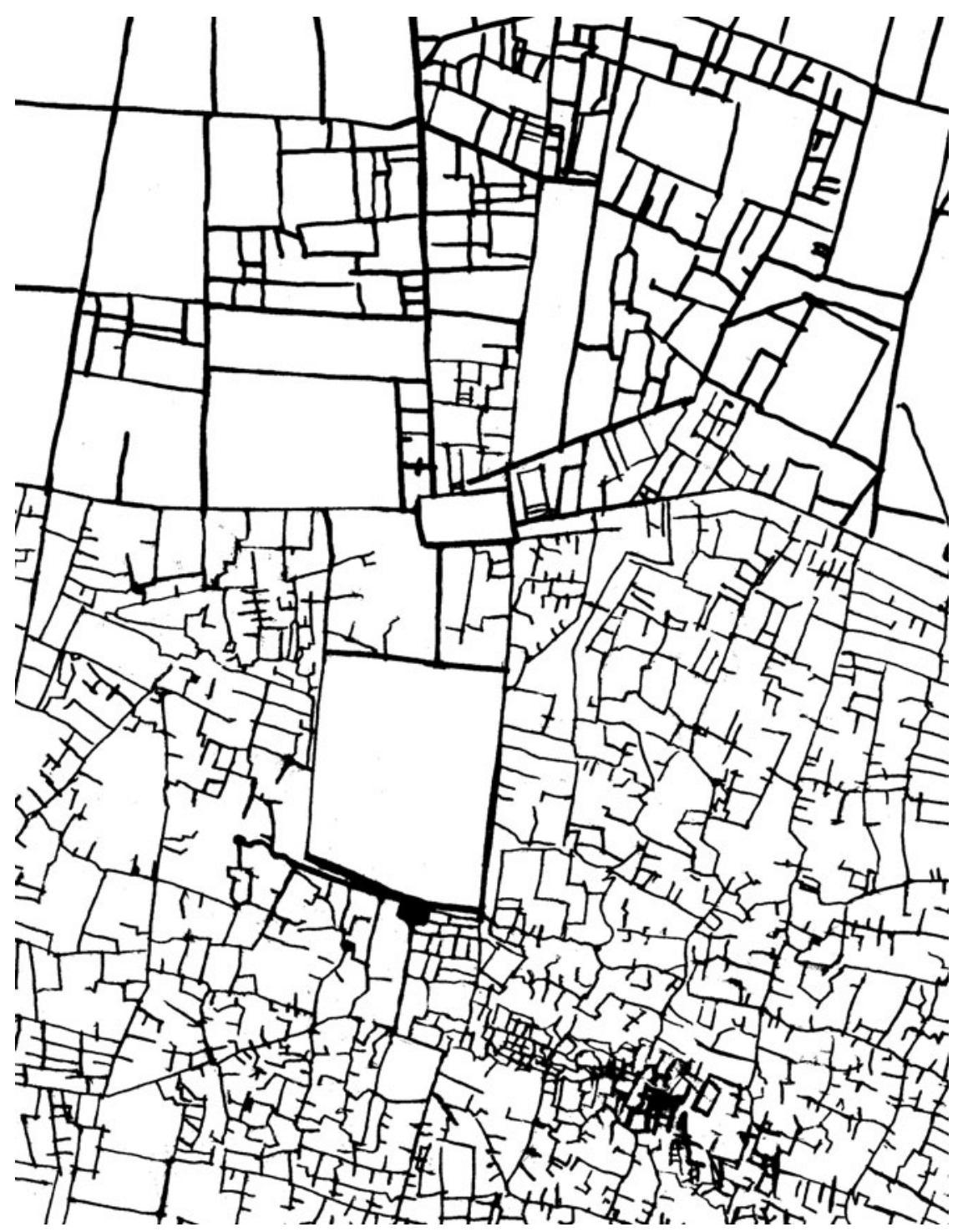

Figure 7: Gridiron pattern of the Naserid extensions in contrast to the organic geometry of the city core, Naserid Tehran 1890, based on Abd-ol-Ghafar Map.

were additions to the existing urban context, and the geometry employed was different from that of the city core (Figure 7). But what differentiates the case of Safavid Isfahan from Naserid Tehran is the way that the new geometries were lived and practised on the ground: in the former case, the new impositions were appropriated by the inhabitants based on the 
regulations derived from their indigenous life-world, but in the latter case, the imposed urban pattern was not only followed and came to dominate in the later period, but became the conventional urban development pattern for the succeeding years, depicting a new morphological paradigmatic shift in the history of urbanism in Iran. 